\title{
Ecology and distribution of the rare copper moss Streptocolea atrata (Bryopsida, Grimmiaceae) in the Czech Republic
}

Ivan Novotný \& Radka Mudrová

\begin{abstract}
Ecology and distribution of the rare copper moss Streptocolea atrata (Bryopsida, Grimmiaceae) in the
\end{abstract} Czech Republic. - Acta Mus. Siles. Sci. Natur., 64: 23-26, 2015.

\begin{abstract}
The current distribution of the moss Streptocolea atrata (Hornsch.) Ochyra \& Żarnowiec (Bryopsida, Grimmiaceae) in the Czech Republic is reviewed. This species is known to occur only in the Giant Mountains and Bohemian Forest in this country. The history of its discovery is presented and all the available specimens are listed and their distribution is indicated in a map. The global distribution of $S$. atrata is briefly commented.
\end{abstract}

Key words: Bohemian Forest, Bryophyta, Central Europe, copper mosses, Giant Mountains, distribution.

\section{Introduction}

Streptocolea atrata (Hornsch.) Ochyra \& Żarnowiec is a medium-sized moss growing in dense, dark to almost black, 1-4 cm tall cushions or tufts. At first sight, it does not look like a member of the Grimmiaceae family because of a lack of hyaline hair-points typical of most of its representatives.

The species exhibits several characters which are unique in the Grimmiaceae, including bulging, mostly bistratose alar cells, spirally twisted vaginula, systylious capsules and a unique shape of the annulus which consists of a single row of paradental cells at the insertion of the peristome (Maier 2002). These traits make it distinct from other species of the large and heterogeneous genus Grimmia Hedw. and indicate its isolated position within the family Grimmiaceae. Ochyra et al. (2003) proposed the new generic name Streptocolea (I.Hagen) Ochyra \& Żarnowiec to accommodate Grimmia atrata.

Streptocolea atrata belongs to the group of so-called copper mosses because of its preference for outcrops of acidic rock which are rich in heavy metals. It occurs on sheltered or exposed cliffs and crags, and is often associated with damp rocks. It also grows in boulder screes and on boulders by lakes from lowland to mountains (Atherton et al. 2010). Streptocolea atrata is a pan-Holarctic oreophyte having a strongly discontinuous geographical range, with most occurrences in the mountains of the southern part of the Holarctic. In addition, it occurs at highly isolated sites in South America, including Bolivia and Brasil (Muñoz 1999). Ecology and global distribution of S. atrata are summarised by Ochyra \& Bednarek Ochyra (2004); since then, additional occurrences of this species have been reported from Taiwan (Blockeel et al. 2006) and Colombia (Ellis et al. 2012).

In continental Europe, Streptocolea atrata is rare and is known from Austria (Grimms 1999), Belgium (De Sloover \& Demaret 1968), France (Maier 2010), Switzerland (Amann 1918) and the Czech Republic. For a long time, just a single Czech locality was known at the southern slope of Mount Sněžka in the Giant Mountains, discovered by Velenovský in 1900 (Velenovský 1901, Pilous \& Duda 1960) and known to persist at the site until recently (Kučera et al. 2004). However, it was unexpectedly reported from the Český les Mts in the south-west of the Czech Republic by Bednarek-Ochyra (cf. Ellis et al. 2014), who discovered specimen of this species collected in 1985 by K. Sutorý, identified as Grimmia sp. in the Moravian Museum herbarium (BRNM). It was collected at this site also by Miloslav Vondráček in 1997 and correctly named as Grimmia atrata. The discovery of Streptocolea 
atrata in a new region of the Czech Republic prompted us to a revision of specimens from the Czech and some of foreign herbaria to reconstruct the history of collecting this species in the country and to obtain some detailed ecological information from the collection sites.

\section{Material and methods}

We studied the herbarium collections of this species in the BRNM, BRNU, CBFS, DUKE, PR, PRC, OP and $\mathrm{W}$ herbaria as well as the herbarium of the The Museum of the Bohemian Forest and the private herbarium of prof. J. Váňa (Prague).

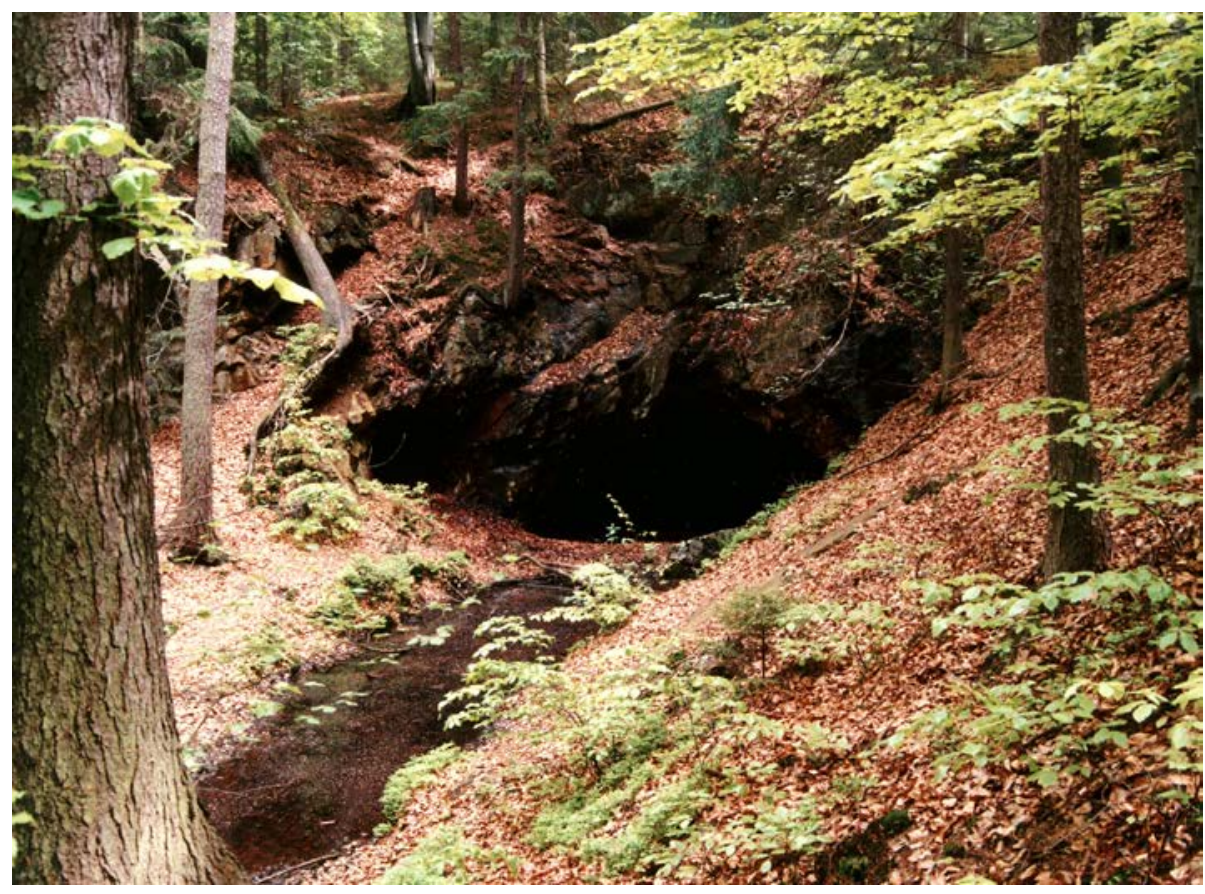

Fig 1: View of Salka hole (photo by P. Mudra, 27. June 2007).

\section{Results and discussion}

Kučera et al. (2004) reported the occurrence of Streptocolea atrata growing on acidic iron-containing rocks in two parts of the ravine in the valley of Rudný potok brook. One population grew at an elevation between $c a .1130$ and $1150 \mathrm{~m}$ a.s.l. (WGS-84, 50 43'52" N, $15^{\circ} 43^{\prime} 56^{\prime \prime} \mathrm{E}$ ), whereas the second one was found shortly above a track at the waterworks at an elevation between $c a .1230$ and $1250 \mathrm{~m}$ a.s.l. ( $\left.\mathrm{N}=50^{\circ} 43^{\prime} 58.5^{\prime \prime}, \mathrm{E}=15^{\circ} 44^{\prime} 01^{\prime \prime}\right)$. The population was estimated to cover about $51 \mathrm{~m}^{2}$ at the first site and about $5.7 \mathrm{~m}^{2}$ at the second site. All specimens collected at this site were sterile Kučera et al. (2004).

In the Bohemian Forest, Streptocolea atrata was collected for the first time by Karel Sutorý on 29 March 1985 on rocks near a mine adit called "Salka" (N=49²3'10", $\mathrm{E}=12^{\circ} 53^{\prime} 24^{\prime \prime}$ ) which has been designated a Nature Monument (Fig 1). The first records of aluminium smelting works come from 1765. The mining activities in this area continued until the end of the 18th century. The flooded hole named "Salka" is the remains of pyritic schist mining. The size of the former aboveground area of mining activities is $20 \times 15 \times 8 \mathrm{~m}$. It is terminated by a sloping hole (http://kpp-kt.klatovsko.cz/salka.html). In the "Skala-Salka" area a log hut was opened in 1943. (http://www.mavlast.cz/top-turisticke-cile.salka). "Salka” was designated a Nature Monument in 1990. It is surrounded by acidic beech forest with admixture of Picea abies. Typical vascular plant species are Vaccinium myrtillus, Dryopteris dilatata, Maianthemum bifolium and Luzula pilosa. The material collected by Karel Sutorý 
was identified in 2007 as S. atrata by Halina Bednarek-Ochyra, who later published a brief note on this discovery (Ellis et al. 2014).

Twelve years after its first collection, Streptocolea atrata was independently collected at this site by Miloslav Vondráček who collected the species on a rock in the "Salka" hole on 20 August 1997. He correctly identified the moss as Grimmia atrata and deposited voucher specimens in the herbarium of the The Museum of the Bohemian Forest. In 2006 this material was verified by J. Kučera. The species still occurs at this site and was collected again in 2007 by R. Mudrová. All specimens from this site are sterile.

At present, Streptocolea atrata is known from two localities in the Czech Republic - see Fig 2. They are both situated in nature reserves. The species is classified as VU (vulnerable) in the Red List of the Czech Republic (Kučera \& al. 2012).

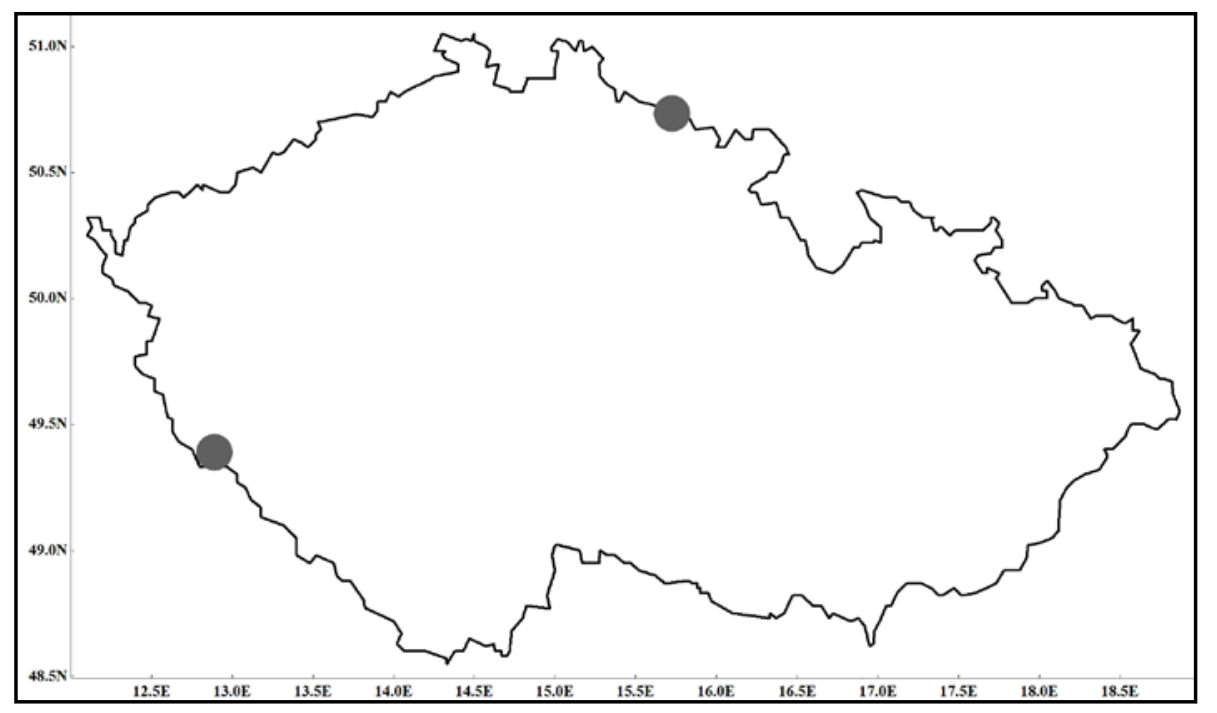

Fig 2: Distribution map of Streptocolea atrata in the Czech Republic

The absence of Streptocolea atrata from the Ore Mountains in the Czech Republic and/or Germany is interesting. We can only speculate about the reason of its absence in the Ore Mountains. We have explored several other adits in 2012 and 2013 where copper had been mined at lower altitudes. One of them lies around Roudné Masty village in eastern Bohemia at $357 \mathrm{~m}$ a.s.1. and several adits are situated in the hill of Měděnec at $660 \mathrm{~m}$ a.s.l. near Nové Město pod Smrkem in northern Bohemia. All these holes were relatively dry. We believe that a stable water content and/or high atmospheric humidity is necessary for occurrence of Streptocolea atrata.

\section{Specimens examined}

Czech Republic, West Bohemia: Bohemian Forest Mts: hole named "Salka” $1 \mathrm{~km} \mathrm{~S} \mathrm{of} \mathrm{the} \mathrm{village} \mathrm{of} \mathrm{Stará}$ Pasečnice, on rocks near the hole, 540-570 m a.s.l., 29 March 1985, K. Sutorý, steril., det. H. Bednarek-Ochyra, 2007 [BRNM 356044, KRAM]; ibid., boulder in front of entrance into the hole, 580 m a.s.l., 20 August 1997, M. Vondráček, steril. [herb. The Museum of the Bohemian Forest 4355]; ibid., 27 June 2007, R. Mudrová, steril. [herb. The Museum of the Bohemian Forest, numberless].

Czech Republic, Northern Bohemia: Giant Mts: on rock above waterfall under top of Mt. Sněžka. by path into Obří důl ravine (Riesengrund), September 1900, J. Velenovský [PRC]; ibid. ex herb. J. Velenovský [BRNM 162169], steril. [Velenovský 1901]; ibid., above mountain blacksmith, on red iron containing rock, ca. $1100 \mathrm{~m}$ a.s.l., 11 July 1905, Jul. Baumgartner, [W], steril.; Mt. Sněžka, 20 May, 21 July, 26 June 1927, 20 September 1927, 20 June 1929, leg. R. Wihan [PR], steril.; ibid., on granite rocks frequently irrigated by vale rivulet below Mt. Sněžka near the village of Rudník, ca. 1200 m a.s.1., Z. Pilous, June 1947, Z. Pilous Musci čechoslovenici 
exsiccati No. 205 [BRNM 162171, BRNU, PR, W], steril.; ibid., below Mt. Sněžka by Rudný potok stream just above the waterwork, 12 May 1947, Z. Pilous [BRNM 97408]; ibid., below Mt.Sněžka near the village of Rudník, ca. 1200 m a.s.l., 7 June 1947, Z. Pilous [herb. Vojtěch Ježek, BRNM 210098], steril.; ibid., village of Rudník below Mt. Sněžka, July 1950, Z. Pilous [BRNM 337771], steril.; ibid., village of Rudník below Mt. Sněžka, 1200 m a.s.l., July 1951, Z. Pilous [BRNM 337867]; ibid., Rudný potok stream, rocks above water tower by path on Mt. Sněžka, ca. 1300 m a.s.l., 9 July 1985, J. Váňa [herb. J. Váňa]; village of Rudník, rocks above Rudný potok stream, ca. 1100 m a.s.l., 5 July 1967, J. Váňa [herb. J. Váňa]; village of Rudník, rocks above Rudný potok stream, ca. 1200 m a.s.l., 8 July 1985, 29 September 1992, J. Váňa [herb. J. Váňa]; ibid., ca. 250 m above pithead, rock by stream, 1100-1150 m a.s.1., 2 June 1998; J. Kučera [CBFS 2865-6, 2877]; ibid., just above the waterwork, rocks at the entrance to the adit, $1220 \mathrm{~m}$ a.s.1., 2 June 1998, J. Kučera [CBFS 2896]; ibid., valley of Rudný potok brook, open S-facing siliceous rock, ca 1100 m a.s.l., 2 June 1998, B. Buryová [DUKE 1581]; ibid., siliceous rock above the bridge near a cave, 1220 m a.s.l., 2 June 1998, B. Buryová [DUKE 1588]; ibid., right bank of Rudný potok brook above the lower pithead, wet half-shaded E-facing gneiss rock, almost vertical face, 20 September 2002, B. Buryová [3804]; SW slope of Sněžka Mt., on siliceous stone, 15001600 m a.s.l., 2 June 1998, B. Buryová [1599].

Acknowledgements: We would like to thank to R. Ochyra for comments on the text of this paper and J.W. Jongepier for English language correction. J. Váňa is acknowledged for his data. B. Shaw and J. Kučera kindly provided their data and contributed to the article with many useful suggestions. The article appears through financial support provided to the Moravian Museum by the Ministry of Culture of the Czech Republic as part of its long-term conceptual development programme for research institutions (ref. MK000094862).

\section{References}

Atherton I., Bosanqut S. \& Lawley M. (2010): Mosses and liverworts of Britain and Ireland a field guide. First edition. Plymouth.

Amann J. (1918): Flore des mousses de la Suisse. Bryogéographie de la Suisse. Lausanne: Imprimeries Réunies.

Blockeel T.L. et al. (2006): New national and regional bryophyte records, 13. - Journal of Bryology 28: 151155.

De Sloover J.-L. \& Demaret F. (1968): Flore générale de Belgique. Bryophytes. Volume III. Fascicule 1, Bruxelles: Ministère de l'Agriculture, Jardin Botanique National de Belgique, pp. 1-112.

Ellis L.T. et al. (2012): New national and regional bryophyte records, 31. - Journal of Bryology 34: 123-134.

- (2014): New national and regional bryophyte records, 39. - Journal of Bryology 35: 134-151.

Grimms F. (1999): Die Laubmoose Österreichs. Catalogus florae Austriae, II. Teil, Bryophyten (Moose), Heft 1, Musci (Laubmoose). Wien: Österreichische Akademie der Wissenschaften.

Kučera J., Zmrhalová M., Buryová B., Plášek V. \& Váňa J. (2004): Bryoflora of the Úpská jáma cirque and adjacent localities of the Eastern Krkonoše Mts. - Čas. Slez. Muz. Opava (A) 53: 143-173.

Kučera J., Váňa J. \& Hradílek Z. (2012): Bryophyte flora of the Czech Republic: updated checklist and Red List and a brief analysis. - Preslia 84: 813-850.

Maier E. (2002): The genus Grimmia (Musci, Grimmiaceae) in the Himalaya. - Candollea 57: 143-238.

- (2010): The genus Grimmia Hedw. (Grimmiaceae, Bryophyta) - a morphological-anatomical study. Candollea 63: 1-377.

Muñoz J. (1999): A revision of Grimmia (Musci, Grimmiaceae) in the Americas. 1: Latin America. - Annals of the Missouri Botanical Garden 86: 118-191.

Ochyra R. \& Bednarek Ochyra H. (2004): Streptocolea atrata (Bryopsida, Grimmiaceae), newly found in Western North America, with a review of its global distribution. - Bryologist 107: 542-549.

Ochyra R., Żarnowiec J. \& Bednarek-Ochyra H. (2003): Census catalogue of Polish mosses. Kraków: Polish Academy of Sciences, Institute of Botany.

Pilous Z. \& Duda J. (1960): Klíč k určování mechorostů ČSR. Praha: Nakladatelství ČSAV.

Velenovský J. (1901): Bryologické příspěvky z Čech za rok 1900-1901. - Rozpravy české akademie císaře Františka Josefa pro vědy, slovesnost a umění, Praha 10(24): 1-12.

Authors' addresses: Ivan Novotný, Moravian Museum, Department of Botany, Hviezdoslavova 29a, CZ-627 00 Brno, Czech Republic. E-mail: inovotny@mzm.cz

Radka Mudrová, The Museum of the Bohemian Forest, Tř́ida Míru 447, CZ-347 01

Tachov, Czech Republic.

E-mail: pmudra@email.cz 